\title{
The structure of permaculture landscapes in the Philippines
}

\author{
JABEZ JOSHUA M. FLORES ${ }^{1, \vartheta}$, INOCENCIO E. BUOT JR., ${ }^{2, v v}$ \\ ${ }^{1}$ School of Environmental Science and Management, University of the Philippines Los Banos. College, Laguna 4031, Philippines \\ remail: jmflores4@up.edu.ph (corresponding author) \\ ${ }^{2}$ Institute of Biological Sciences, College of Arts and Sciences, University of the Philippines Banos. College, Laguna 4031, Philippines \\ vemail: iebuot@up.edu.ph
}

Manuscript received: 17 March 2021. Revision accepted: 27 March 2021

\begin{abstract}
Flores JJM, Buot Jr. IE. 2021. The structure of permaculture landscapes in the Philippines. Biodiversitas 22: $2032-2044$. Biodiversity plays a crucial role in sustainable agriculture. Permaculture is a design philosophy that values this role as it consciously integrates diverse components into the farm landscape. The purpose of the study was to characterize the general structure of permaculture landscapes in the Philippines and identify the landscape components that comprise its farming systems. The research was conducted in 12 permaculture farms in 11 provinces in the Philippines in 2018. Aerial photography and farm inventory were employed for data collection. A crop diversity survey was conducted using a modified belt transect method with alternating $20 \mathrm{~m}^{2}$ plots within a 1 ha sampling area. Full enumeration of plant species in each plot was performed to determine species richness and samples were manually counted to compute for the Shannon-Wiener Diversity Index. Results of the study showed that permaculture landscapes were organized into six spatial zones: 'house,' 'garden,' 'grazing,' 'cash crops,' 'food forest,' and 'wilderness.' It was identified that each zone contained components belonging to six categories: abiotic, biotic, man-made structural, technological, socio-economic, and cultural. 'Biotic' results showed that all sites recorded high species richness (>20-65) with the highest found in Glinoga Organic Farm with 65. Aloha House in Palawan had the highest diversity with a score of 0.311 . An analysis of the ratio of plant species per plant category showed that the vegetable/cereal crops dominated the landscape in $50 \%$ of sites. While $20 \%$ were characterized by tree/fruitbearing crops. Perennial species were the most abundant in all sites with $75-95 \%$ of the total plant species. In conclusion, permaculture provided a design framework for restructuring our agricultural landscapes into diverse and productive ecosystems for human settlement and food production.
\end{abstract}

Keywords: Agroecology, agroecosystems, biodiversity, diversified farming systems, ecological network, landscape ecology

\section{INTRODUCTION}

A fast-growing global population leading to increased demand for staple food crops has given way to massive agricultural practices of monoculture (Kremen et al. 2012). But the homogenization of landscapes has resulted in soil degradation (Borelli et al. 2020; Borelli et al. 2017), loss of biodiversity (Le Roux et al. 2019) and its natural habitats (Goncalves-Souza 2020), and tradeoffs in the delivery of ecosystem services (Power 2010; Hirschfeld and Van Acker 2021). However, agriculture has remained to be largely a plantation type of enhancing food security and hence, the survival of the human race. In the long run, however, this is undoubtedly counter-productive and unsustainable.

To address the disruptive effects of massive agricultural practices, permaculture, as an alternative, presents a major paradigm shift that aims to mimic the complexity and resilience of natural systems manifested in the design of agricultural landscape structures. Mollison (1988) described permaculture as 'a system of assembling conceptual, material, and strategic components in a pattern which functions to benefit life in all its forms'. This system, when applied to agriculture, creates complex, diverse, and multifunctional landscapes. However, such diverse landscapes share common features which seek to achieve household food security while being conscious of biodiversity.

Permaculture landscapes have been studied in various countries like Japan (Chakroun 2019), Malawi (Kamchacha 2013), and Malaysia (Ismail and Affendi 2015). Such landscapes were characterized by agroforestry systems, free-range grazing (Krebs and Bach 2018), swale systems (Ismail and Affendi 2015), greywater collection systems (Rivett et al. 2017), forest edges (Krebs and Bach 2018), food forest (Kelly-Bisson 2013), and edible gardens (Ismail and Affendi 2015).

In the Philippines, however, the few existing studies on permaculture have created a knowledge gap on the design and structural characteristics of permaculture landscapes which demonstrates how the system can actually contribute to household food security. To address this knowledge gap, the study aimed to characterize the structure of permaculture landscapes and identify landscape components in permaculture. 


\section{MATERIALS AND METHODS}

\section{Study area}

Twelve (12) permaculture sites representing the three major island groups of the Philippines, i.e. Luzon (9), Visayas (2), and Mindanao (1) were selected for the study (Figure 1). Sites were sampled from a database of permaculture practitioners in the Philippines using maximum variation sampling (Cohen and Crabtree 2006). Climate type, land area, geographic location, as well as availability of the respondents, were the factors considered for selecting study sites. Three days were allocated for data collection at each site. Fieldwork was conducted from August 31 to November 6, 2018.

\section{Characterization of landscape structure}

Determination of zones and system boundaries. Respondents were requested to conduct a detailed farm tour to explain the general design and zoning plan of the site. Aerial photographs using DJI Spark and Ryze Tello drones were taken with permission to use as reference. Farm property boundaries were marked and geotagged using a Trimble TDC600 global positioning system (GPS) device. Upon review of aerial photos and GPS coordinates, zone plan and system boundaries were determined and plotted on Google Earth Pro.

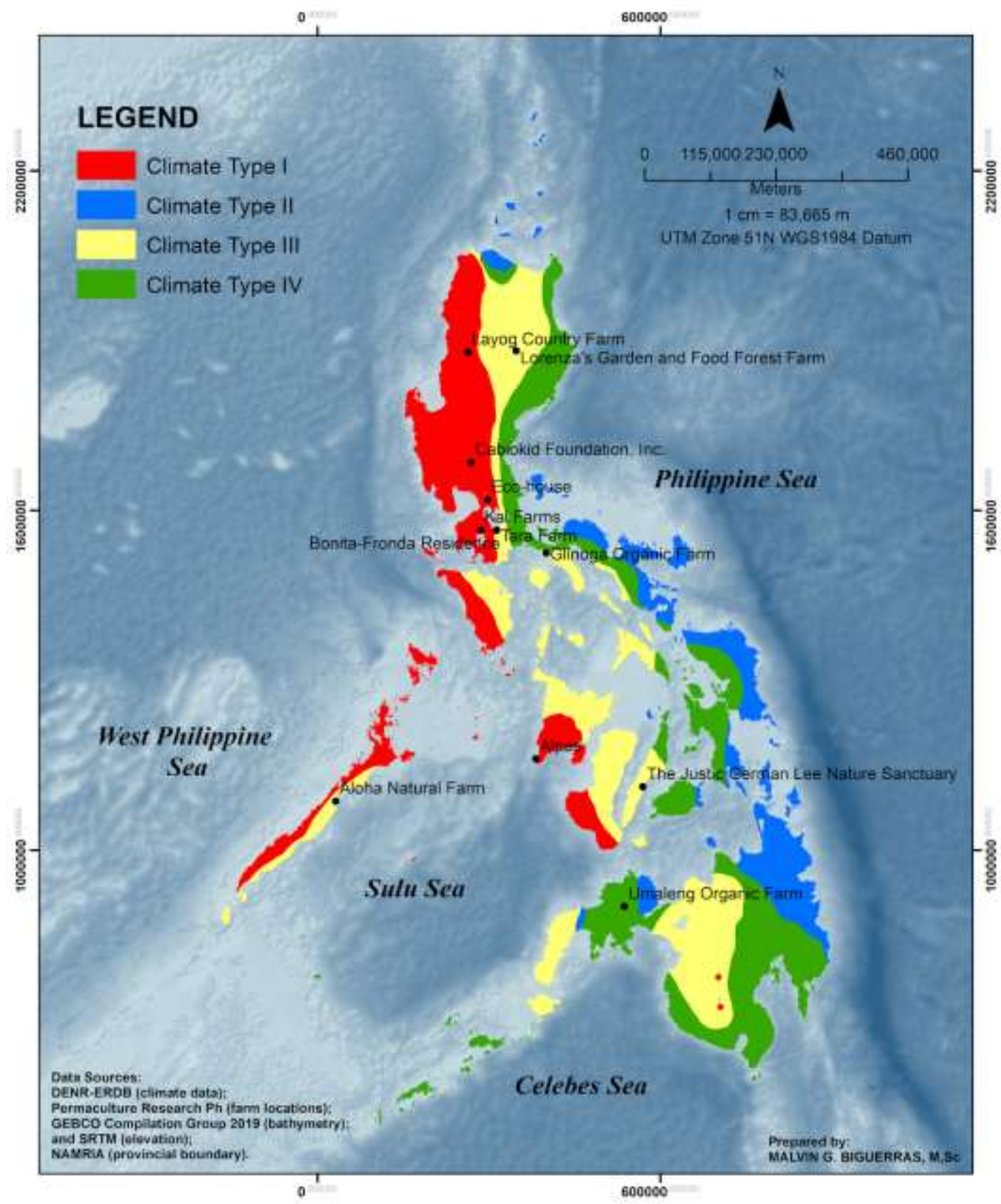

Figure 1. Study sites on a climate map of the Philippines Twelve permaculture sites were discovered in the study. Shown in the map are the locations overlaid on climate type data: 5 sites in Type 1, 6 sites in Type 3, and 1 in Type 4 . 
Identification of landscape components. To characterize the landscape structure, ground-truthing of landscape elements, or discrete objects (Antrop and Van Eetvelde 2017), was performed using direct observation and manual counting to create a farm inventory. Man-made landscape elements (i.e. built structures, machinery, and installations) and continuous landscape features, or components (Antrop and Van Eetvelde 2017), such as bodies of water and natural land formations were fully enumerated, geotagged, and recorded on a field datasheet. Both 'discrete objects' and 'continuous landscape features' are referred to as 'components' in the study.

For biotic components (flora and fauna), a modified belt transect method (Grant et al. 2004) was used in a 1-ha sampling grid (Figure 2). In this method, two intersecting 100-m transect lines labeled 'A-T' on the $\mathrm{x}$-axis and '1-20' on the y-axis were set up using colored nylon ropes and 1$\mathrm{m}$ long orange PVC pipes labeled with a corresponding alphanumeric code (i.e. Plot A-10) to indicate location on the grid. Alternating $20-\mathrm{m}^{2}$ plots were placed $5 \mathrm{~m}$ apart along the two transect lines for a total of 38 plots. Full enumeration of species on each plot was conducted to determine species richness and sample populations were counted in each plot to compute the Shannon-Wiener Diversity Index using the formula (Shannon and Weaver 1949; Wiener 1939; Wiener 1948; Wiener 1949):

$$
H^{\prime}=-\sum_{i=1}^{s} p_{i} \ln p_{i}
$$

Soil samples were also collected in the same plots for in situ colorimetric soil test analysis using a rapid soil test kit.

\section{RESULTS AND DISCUSSION}

\section{Characterization of landscape structure}

Design and function of permaculture zones. A brief overview of the twelve permaculture sites is shown in Table 1. Nine are located in Luzon in the provinces of
Cavite, Isabela, Laguna (2 sites), Metro Manila, Mountain Province, Nueva Ecija, Palawan, and Quezon; two are located in Visayas in the provinces of Antique and Cebu; and one is located in Mindanao in the province of Zamboanga del Sur.

Figure 3 shows that the permaculture farms in the sites were designed into six zones (Babac 2018) which were named based on the most dominant or most common components. The zones are Zone 0 (House), Zone 1 (Garden), Zone 2 (Grazing), Zone 3 (Cash Crops), Zone 4 (Food Forest), and Zone 5 (Wilderness). Zone labels "0-5" are based on Mollison (1988). Each zone will be discussed here in terms of landscape layout and composition.

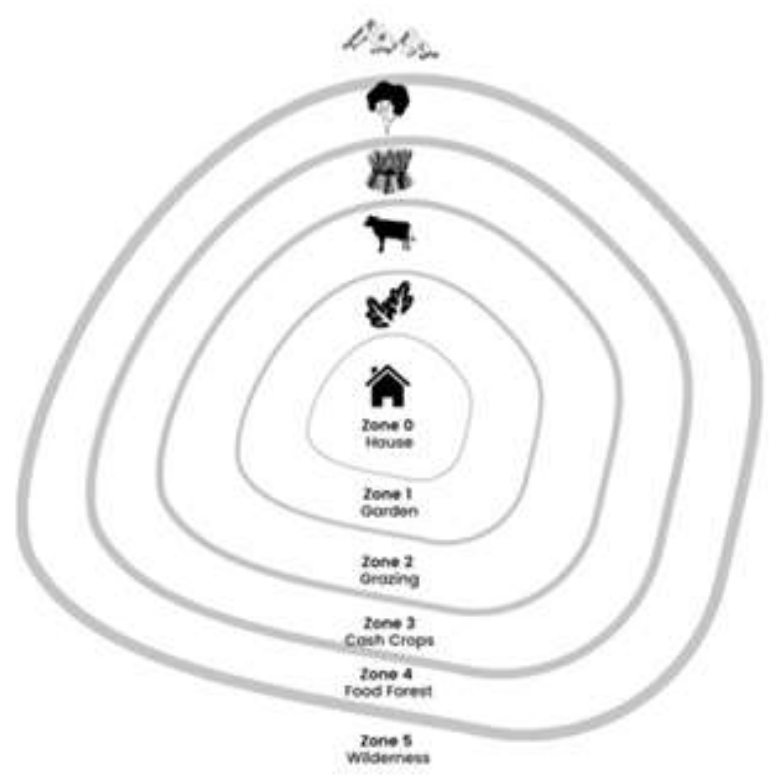

Figure 3. The permaculture landscape structure is characterized in this study by 6 zones: Zone 0 (house), Zone 1 (garden), Zone 2 (grazing), Zone 3 (cash crops), Zone 4 (food forest), and Zone 5 (wilderness).

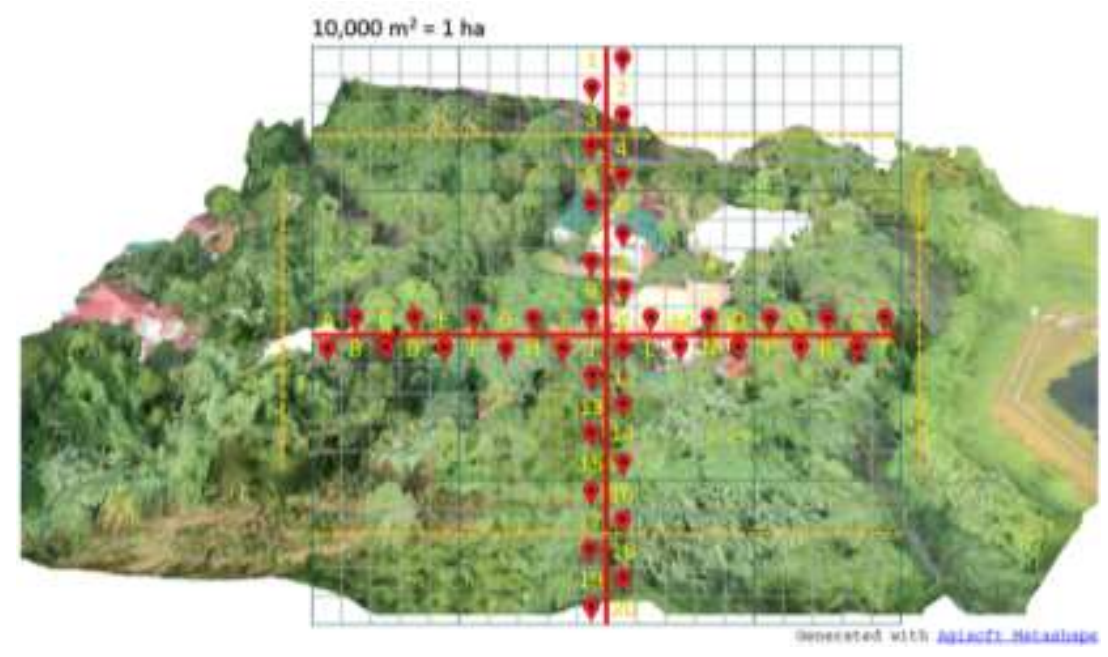

Figure 2. Sampling method for biotic components. A modified belt transect sampling method was used to identify the species richness and diversity of biotic landscape elements such as vegetable crops and livestock (3D model by Agisoft Photoscan, 2016). 
Table 1. Overview of permaculture study sites showing location (province), land area, elevation profile, and description of the site's characteristics and main functions

\begin{tabular}{|c|c|c|c|}
\hline Study site & Complete name & $\begin{array}{l}\text { Land area (ha) } \& \\
\text { elevation profile } \\
\text { (min-max m asl.) }\end{array}$ & Brief description of the permaculture site \\
\hline $\begin{array}{l}\text { Aloha } \\
\text { House }\end{array}$ & Aloha House Inc., Palawan & $\begin{array}{l}0.28 \text { ha } \\
52-40 \mathrm{~m} \text { asl. }\end{array}$ & $\begin{array}{l}\text { A residential area and diversified organic urban farm based on an } \\
\text { aquaponic system; features an orphanage, bed and breakfast } \\
\text { services, and natural farming training services. }\end{array}$ \\
\hline Alpas & Alpas Resort, Antique & $\begin{array}{l}0.75 \mathrm{ha} \\
14-10 \mathrm{~m} \text { asl. }\end{array}$ & $\begin{array}{l}\text { A coastal private property with access to beachfront, } \\
\text { accommodation facility and restaurant service that specializes in } \\
\text { local cuisine while advocating the use of local products; features } \\
\text { an herb and vegetable garden with fruit trees. }\end{array}$ \\
\hline Cabiokid & $\begin{array}{l}\text { Cabiokid Foundation Inc., } \\
\text { Nueva Ecija }\end{array}$ & $\begin{array}{l}9.77 \text { ha } \\
14-10 \mathrm{~m} \text { asl. }\end{array}$ & $\begin{array}{l}\text { A diversified organic farm featuring rainwater catchment ponds } \\
\text { for aquaculture and dry season irrigation; farm is buffered by } \\
\text { thick forest edges that function as wildlife corridor and habitat. }\end{array}$ \\
\hline Eco-house & $\begin{array}{l}\text { Eco-house - The Philippine } \\
\text { Permaculture Association } \\
\text { office, Metro Manila }\end{array}$ & $\begin{array}{l}0.033 \mathrm{ha} \\
52-40 \mathrm{~m} \text { asl. }\end{array}$ & $\begin{array}{l}\text { A residential home made of clay-cement mixture; features a } \\
\text { rainwater harvesting system, solar power system, and home } \\
\text { garden with small fish pond. Office of the Philippine } \\
\text { Permaculture Association. }\end{array}$ \\
\hline Glinoga & $\begin{array}{l}\text { Glinoga Organic Farm, } \\
\text { Quezon }\end{array}$ & $\begin{array}{l}20.50 \text { ha } \\
21-14 \mathrm{~m} \text { asl. }\end{array}$ & $\begin{array}{l}\text { A diversified organic farm located within a mangrove ecosystem } \\
\text { and rice-coconut agroecosystem; focuses on hyperlocal food } \\
\text { production and value-added products using natural farming } \\
\text { techniques. }\end{array}$ \\
\hline Jubileeville & $\begin{array}{l}\text { Bonita-Foronda Residence, } \\
\text { Laguna }\end{array}$ & $\begin{array}{l}0.35 \text { ha } \\
24-20 \mathrm{~m} \text { asl. }\end{array}$ & $\begin{array}{l}\text { A residential home with perennial tree crops and backyard garden } \\
\text { irrigated by a swale system and a manmade rainwater catchment } \\
\text { pond. }\end{array}$ \\
\hline Kai Farms & Kai Farms, Cavite & $\begin{array}{l}8.68 \text { ha } \\
464-422 \mathrm{~m} \text { asl. }\end{array}$ & $\begin{array}{l}\text { An organic farm featuring multi-cropped vegetables, herbs, and } \\
\text { fruit trees; uses plant-based compost and plant-based, zero-waste } \\
\text { packaging materials; advocates seed-saving. }\end{array}$ \\
\hline Lorenza's & $\begin{array}{l}\text { Lorenza's Garden and Food } \\
\text { Forest Farm, Isabela }\end{array}$ & $\begin{array}{l}1.00 \mathrm{ha} \\
128-124 \mathrm{~m} \text { asl. }\end{array}$ & $\begin{array}{l}\text { An isolated do-it-yourself homestead property (under } \\
\text { construction) with a vegetable and herb garden buffered by native } \\
\text { trees around the perimeter. }\end{array}$ \\
\hline $\begin{array}{l}\text { Nature } \\
\text { Sanctuary }\end{array}$ & $\begin{array}{l}\text { The Justice German Lee Jr. } \\
\text { Nature Sanctuary, Cebu }\end{array}$ & $\begin{array}{l}3.73 \mathrm{ha} \\
11-0 \mathrm{~m} \text { asl. }\end{array}$ & $\begin{array}{l}\text { Mangrove and coastal forest ecosystems featuring a complex } \\
\text { system of meandering swales; features bamboo structures, } \\
\text { compost toilet system, and a variety of appropriate technologies. }\end{array}$ \\
\hline Olaussen & $\begin{array}{l}\text { Olaussen Permaculture } \\
\text { Park in Layog Country } \\
\text { Farm, Mountain Province }\end{array}$ & $\begin{array}{l}0.54 \text { ha } \\
912-864 \mathrm{~m} \text { asl. }\end{array}$ & $\begin{array}{l}\text { A diversified upland organic farm located on an ancestral } \\
\text { property with indigenous Igorot origins called Layog Country } \\
\text { Farm; emphasizes foraging and preservation of indigenous culture } \\
\text { through food and farming }\end{array}$ \\
\hline Tara Farms & Tara Farms, Laguna & $\begin{array}{l}1.00 \mathrm{ha} \\
22-18 \mathrm{~m} \text { asl. }\end{array}$ & $\begin{array}{l}\text { A residential farm-resort setup with rice production, organic herbs } \\
\text { and vegetables, and free-range native pigs. }\end{array}$ \\
\hline UmaLeng & $\begin{array}{l}\text { UmaLeng Organic Farm, } \\
\text { Zamboanga del Sur }\end{array}$ & $\begin{array}{l}2.16 \text { ha } \\
52-50 \mathrm{~m} \text { asl. }\end{array}$ & $\begin{array}{l}\text { A rice-duck integrated farming system with aquaculture, organic } \\
\text { herb and vegetable pocket gardens, fruit orchard, and organic } \\
\text { soap production facility. }\end{array}$ \\
\hline
\end{tabular}

Zone 0. The 'house' is the section of the permaculture landscape where the main place of residence is located. This area features shelters built from renewable materials (Van der Lugt 2006) such as Bambusoideae sp. (bamboo) in Nature Sanctuary and UmaLeng, Corypha elata (buri palm) and Saribus rotondifolius (anahaw) in Glinoga. Other houses were traditionally constructed with concrete and lumber. Zone 0 was observed to be the center of human activities and was the most frequented area by people according to interviews and direct observations. Some of the activities observed here include cooking and dining, sleeping and resting, vegetable packing, receiving guests and social activities. Food processing either for personal use or for selling was also observed to be conducted in this area. As the most frequently used zone, the design of the main house was a priority of all practitioners in their permaculture strategy before expanding into the management of outer zones. Since all sites are privately owned, selecting the location of Zone 0 suggests that permaculture practitioners have control in the design of the farm landscape. 
Comparing our findings with other countries we can see that these Zone 0 design features are not unique to the Philippines setting. Similar designs were also documented in permaculture sites in Indonesia (Putro and Miyaura 2020). As for the components, assemblies of green innovations, do-it-yourself systems, and appropriate technologies are very common features in permaculture houses around the world. Greywater treatment systems and composters, were documented in communal ecovillages in Brazil (Abdala and Mocellin 2010) and in middle-income households in Turkey (Abiral 2019). In Vietnam, human excreta fertilizer from compost toilets is a common practice (Jensen et al. 2008.)

Zone 1. The 'garden' zone contains crops for household consumption and plants for aesthetic purposes (Sofo and Sofo 2020). It is located right next to Zone 0. As shown in Figure 4, it is characterized by a mixed cropping system (Theunissen 1994). The zone's primary function is to provide accessible fresh food to the household, particularly edible herbs (i.e. Origanum vulgare, Ocimum basilicum) and vegetable crops (i.e. Solanum melongena, Abelmoschus esculentus) for daily consumption and subsistence (Putro \& Miyaura 2020). Ornamental and flowering (i.e. Cosmos bipinnatus, Sansevieria trifasciata) plants provide aesthetic function in this area (Khachatryan et al. 2020). Activities observed were seed sorting and sowing, compost-making, potting and transplanting, watering of plants, and mulching of garden beds with dried grass and leaves. Vegetable gardens such as these are also common components in households in South Africa and Zimbabwe (Didarali \& Gambiza 2019) as well as Japan (Chakroun 2019). According to Putro and Miyauro (2020) permaculture home gardens in Indonesia (Putro and Miyaura 2020) are based on the traditional pekarangan system (Kaswanto and Nakagoshi 2014).

Zone 2. The 'grazing' zone is an area for livestock grazing (Kariuki et al. 2021), farm animals, and aquaculture. It is located further away from the house and is usually a large open space. This area was observed to have a mixture of various grass species and forage crops for animals. The zone is mainly used for free-range grazing of livestock (goat, pigs, carabaos) such as in Glinoga and Tara Farms. And for sites that have ponds like Aloha House and Cabiokid, aquaculture is also practiced here. Since the animals forage on their own, minimal human activity and supervision were observed in this zone. In some sites, surplus vegetables from garden zones are fed to animals which are common in crop-livestock landscapes. Research has shown that crop-livestock systems are common in small-scale farms in Asia and are beneficial for ecosystem health and rural livelihoods (Paris 2002; Devendra and Thomas 2002).

Zone 3. This is the 'cash crop' zone which interfaces with the grazing area and food forest zones (Figure 5). A larger area compared to the previous zones, this zone is mainly characterized by crops for commercial use but sometimes merges with Zone 2 during fallow period according to interviews. Majority of human activities performed in this zone occurs only during planting season and harvest time. Most cash crop zones documented were rice fields thus component composition changes every season. Similar to Zone 2, growing cash crops such as grains are prone to monoculture management for costeffective harvesting in order to maximize production (Gabriel et al. 2013). In most countries, agricultural landscapes are mostly characterized and dominated by single-crop plantations such as wheat and corn (USDA 2019), oil palm (Elaeis guineensis) in Indonesia (Rist et al. 2010), while rice fields cover 48 million hectares of land in Southeast Asia alone in 2010 (FAOSTAT 2012). On the agricultural landscape matrix, patches of other plant species are rarely seen.

Zone 4. The 'food forest' zone is located in the furthest area of the farm. Photographic evidence showed that this zone is dominated by trees as it provides a buffer zone from the surrounding environment. This is most evident in Cabiokid, Lorenza's, and Nature Sanctuary (Figure 6). The food forest is characterized by an agroforestry system of production wherein perennial crop species are grown for fruits, timber, and fuelwood. Similarly, fruit tree agroforestry systems in Vietnam (Do et al. 2020) have reported having the same characteristics while yielding higher profits compared to single-crop systems. The food forests observed were primarily composed of fruit-bearing trees such as coconuts, cacao, mango and multipurpose crops such as bananas and bamboo, forming dense forestlike assemblies of trees and shrubs either in patches or corridors enclosing the farm. Minimal activity was observed in this zone except for the occasional harvesting of fruits and timber when needed. In Malaysia (Ismail \& Affendi 2015), the concept of food forest is often applied in urban environments to reintroduce biodiversity and promote food security. A fairly recent concept, The Picasso Food Forest in Italy is one example of a well-documented case study of a food forest that has provided a habitat for plant and wildlife species as well as nurseries for heirloom seed varieties (Riolo 2018).

Zone 5. The last zone observed in permaculture designs is the 'wilderness' zone. Often located outside of the farm property and beyond private management, it is still considered by practitioners as part of the overall design plan. The wilderness is more of a 'philosophical' feature of the permaculture landscape that provides the practitioner with design inspirations from nature. Examples of which are the montane forests in Olaussen, the coastline in Alpas, the mangroves in Glinoga and Nature Sanctuary, and the mountain range in Lorenza's. For farms with a wilderness within the property such as in Cabiokid and Jubileeville, the zone functions to reintroduce biodiversity. Biodiversity conservation in agroecosystems is the closest parallel to this concept (Piratelli et al. 2019). Since Zone 5 as a design feature is often beyond farm management, the practical use of this zone has not yet been formally studied in scientific literature. 

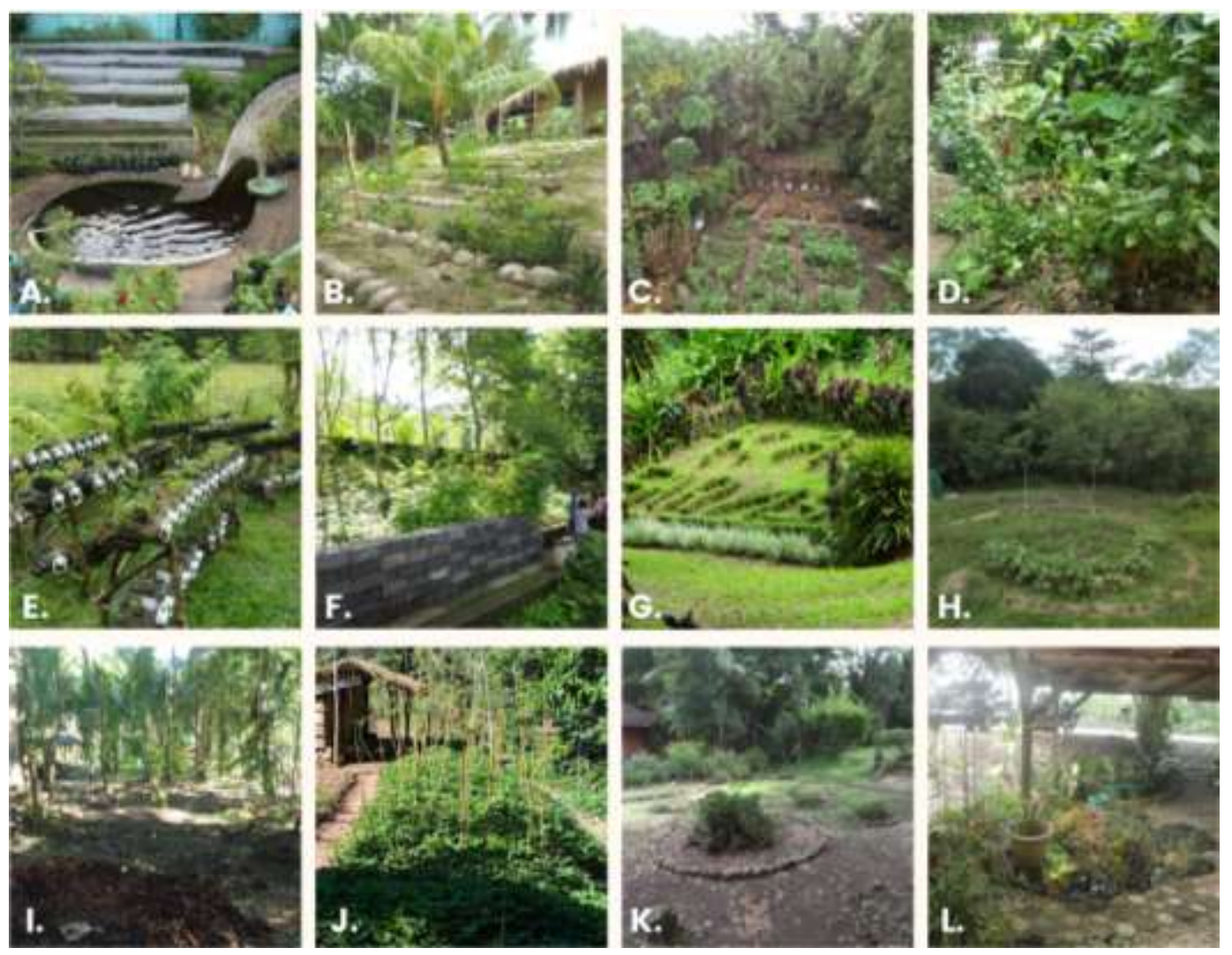

Figure 4. Zone 1 garden zones are characterized by mixed cropping systems of annual and perennial species for subsistence and aesthetic functions. Raised beds (some with unique curved features), hugelkultur, and mulching are common techniques.
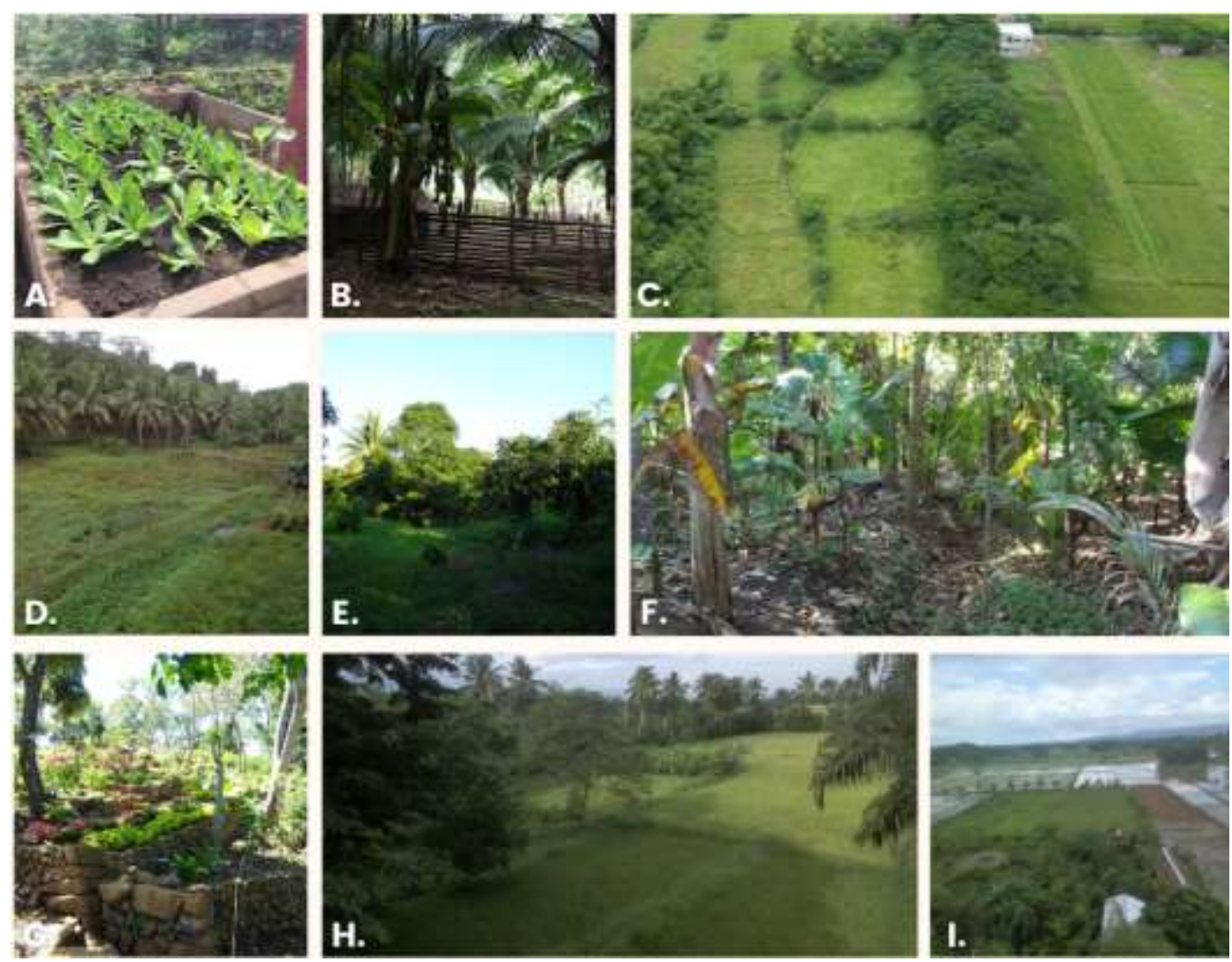

Figure 5. Cash crops in the Zone 3 landscape were mainly characterized by rice (C, D, H, I). In other sites, fruit trees like coconut and banana interfaces into the food forest in Zone 4 (F, B). Some sites deviate from the pattern with raised beds of annual vegetables (A) and a garden of ornamental plants $(\mathrm{G})$. 

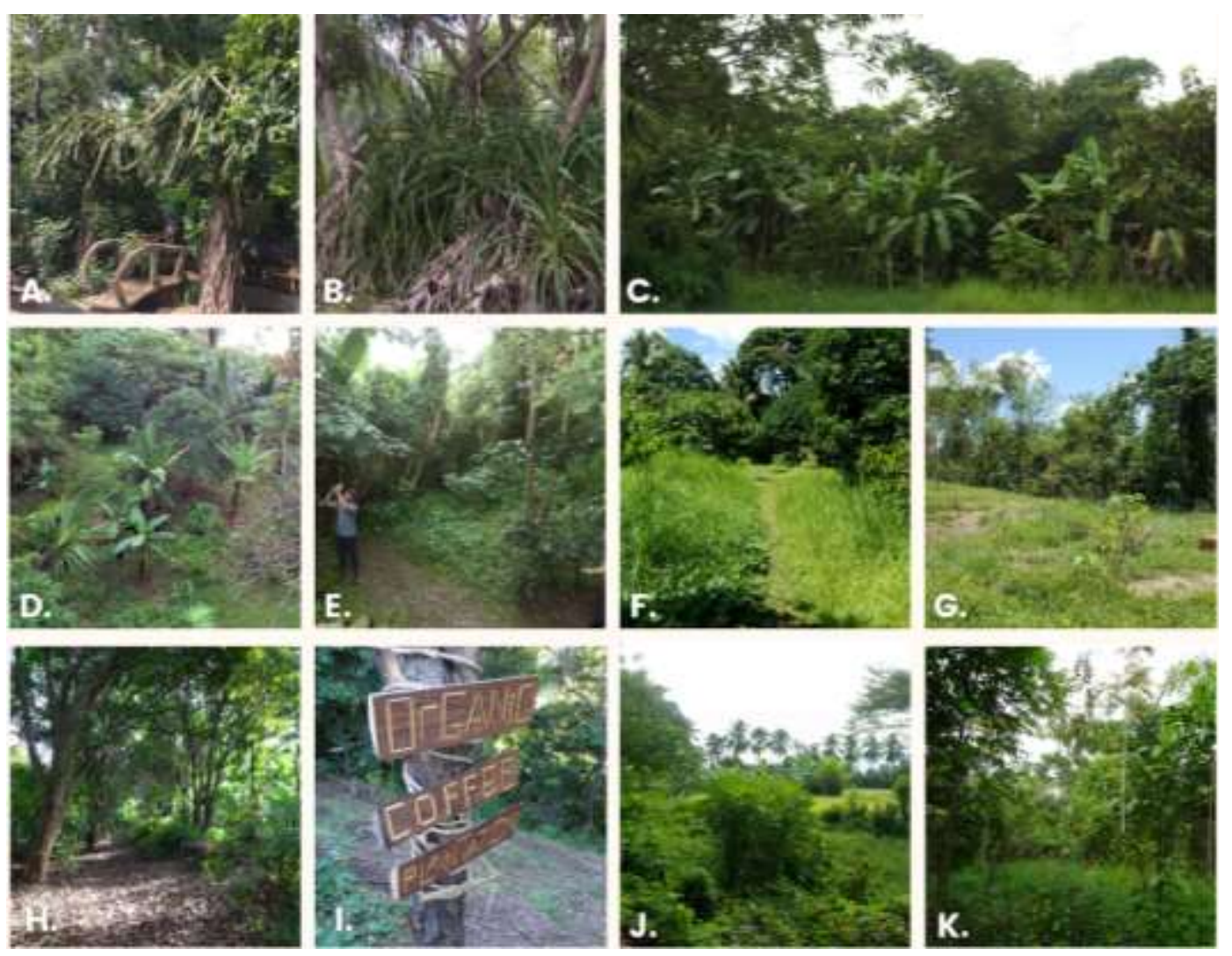

Figure 6. The food forest landscape in Zone 4 is characterized by mixed perennial crops from the forest floor, understory, and canopy. In one site it is integrated with organic coffee trees (I). The zone serves as a source of food, fuelwood, and building materials. It also functions as a wildlife corridor, windbreak (shelterbelt), and soil erosion control.

Zoning in the Philippines, from zones 0 to 5 , are consistent with existing literature (Mollison 1988; Hemenway 2009; Whitefield 2004; Kruger 2015; Bhandari and Bista 2019). However, the distinction between Zones 2 and 3 becomes obscured because livestock and other farm animals graze in the field during the fallow period. While there is no specific research yet on the effectiveness of strategically placing agricultural components in zones to increase crop productivity and resilience in permaculture farms (Krebs and Bach 2018), time-tested socio-ecological practices such as satoyama in Japan and the muyong system in Northern Philippines has proven that subsistence farming, cash crops, and woodlots can sustainably coexist on mosaic landscapes to provide food security and biodiversity (Buot and Osumi 2004). In Europe, a non-governmental scheme called Conservation Grade, suggested that nature (or Zone 5 - Wilderness), should comprise at least $10 \%$ of farm areas (Science for Environment Policy 2017).

Shapes and land area of zones also varied from each site. Zoning as a practice optimized the movement patterns of people, maximizing duration of interaction in nearby zones while avoiding frequent visits to areas that have selfsustaining biotic components like perennial crops (i.e. coconuts) and abiotic features (i.e. ponds). The zoning strategy was reported to be especially effective in permaculture sites with large land areas and limited manpower such as in the cases of Nature Sanctuary,
Cabiokid, and Glinoga. Knowledge on permaculture zones remains largely confined within the theoretical assumptions from Mollison (1988). Whether this design pattern has been accurately incorporated into the farm management of permaculture landscapes has yet to be the subject of further scientific study. However, a similar landscape zone pattern (composed only of three zones: economic zone, combined zone, and natural zone) as proposed by Ferwerda (2016) mirrors permaculture zoning albeit in a larger landscape scale as demonstrated in landscape restoration projects in Spain, South Africa, Australia, and The Netherlands.

\section{Identified landscape components}

Component distribution. Figure 7 shows the number of landscape components observed in each zone. Components that were frequently used (i.e. houses, vehicles) and those in need of closer attention (i.e. vegetable crops) were located in inner zones (0-2). Outer zones contain components that only need minimal attention such as fruit trees and other perennial species.

Component categories. Table 2 reports a total of 1,182 system components recorded in all twelve sites with an average of 99 components per site. Among all sites, Glinoga had the most number of total components with 133 suggesting characteristics of a diverse farm landscape. In contrast, Jubileeville, a residential property, had the least number of total components with 56 . The most number of 
components observed were biotic (678) followed by technological components (244) which demonstrates how daily life and farm management is supported by the use of technology. On the other hand, socio-economic components recorded the least number due to limited infrastructure for on-site agribusiness operations through 10 sites were promoting agritourism and ecotourism. The dominance of biotic components in $90 \%$ of study sites demonstrated how permaculture designs emphasized biodiversity in the design of its landscapes which are complementary to those implementing diversified farming systems in the US (Ferguson and Lovell 2017), socioecological landscapes in Bulgaria (Brawner 2015), and satoyama in Japan (Chakroun and Droz 2020). This diversity of components on the landscape is a stark contrast to the design of monoculture farms (Dmitri et al. 2005).

The 'abiotic' components observed included physical land features (i.e. hill slopes in Glinoga and Lorenza's, swales in Nature Sanctuary and Jubileeville) and water bodies (i.e. ponds in Cabiokid and Tara Farms and irrigation canals in UmaLeng). Also known as continuous landscape elements, these landscape components were either naturally-formed or manmade features designed according to the existing topography found in Zones 1 to 4 . This technique of incorporating natural features was especially advantageous to farms with uneven or sloping landscapes (i.e. Glinoga, Jubileeville) to store and maximize rainwater (Ekka et al. 2021). In cases wherein the landscape is on level ground, 'earthworks' were performed to provide contours and gradations to direct water flow into man-made ponds for irrigation (Vico et al. 2020). Such were the cases in Cabiokid and Nature Sanctuary. Similarly, a design called 'borehole permaculture' in Malawi uses the same principle to avoid creation of stagnant ponds from spilled water which is diverted to irrigate gardens (Rivett et al. 2017).

Soil was also considered as an abiotic component. Results of the colorimetric soil analysis using a rapid soil test kit (Detera et al. 2014) reported generally sufficient levels of soil $\mathrm{pH}$, nitrogen, phosphorus, and potassium for crop production across all sites as reported in Table 3. Given its 'continuous' nature, abiotic components are expectedly few on the landscape but they serve a central function for the spatial arrangement of other components. Similar to soil, waterways are also abiotic components. The Mekong river system is an example of a waterway abiotic component that provides multiple ecosystem services for the benefit of rice and aquaculture farm systems in the Lower Mekong Basin (LMB) which includes countries such as Thailand, Lao-PDR, Cambodia, Vietnam (USAID 2016).

'Biotic' components were found to be the most abundant in the landscape with an average of 57 per site. Although not all biotic components documented were cash crops, this was a significantly large number compared to commercial farms in the United States which only have an average of one crop per farm (Dmitri et al. 2005). Even diversified coconut farms in the Philippines only have 2 to 4 crops per farm (PCARRD 1993). Among those considered as biotic components were plant species, farm animals, wildlife, and the people themselves who live and work on the farm. Components that need minimal attention like grazing livestock (i.e. pigs, goats, carabaos) and fruit trees were situated in Zones 2, 3, and 4. Integration of mixed species (Kremen and Miles 2012) was found to be beneficial to the permaculture landscape. Examples of these were native pigs in Tara Farms which consumed excess vegetation and the mangrove forest in Nature Sanctuary which provided subsistence to the household and habitat for avifaunal species. In the US, the integration of livestock (Zone 2) into corn cropping systems (Zone 3) was found to increase soil organic matter and nutrient content (Maughan et al. 2009). Whereas in Asia, fish were integrated into rice paddy systems to regulate weed growth and pests. Fish as a biotic component also increased nutrient availability in soil and improved crop yields (Berg 2002).

Table 4 reports that all permaculture sites reported high crop diversity in terms of the number of plant species observed (>20-65) in a 1-ha sampling area. Twenty-one (21) species were documented in the Eco-house, the lowest species richness (SR), while 65 species were recorded in Glinoga, the highest recorded SR. Shannon-Wiener Diversity Index $(\mathrm{H})$ revealed that Aloha House was the most diverse with a score of 0.311 while Nature Sanctuary had the lowest with an index score of 0.583 . Analyzing the ratio of plant species per plant category showed that the 'vegetable/cereal crop' use category dominated the landscape in $50 \%$ of permaculture sites. On the other hand, $20 \%$ of sites were characterized by 'tree/fruit-bearing crops.' In all sites, perennial species were the most abundant with $75-95 \%$ of the total plant species found on the landscape. These results validate that permaculture landscapes rely on the cultivation of less-intensive perennial species (Mollison 1988). In the US, 35 permaculture farms were documented by Ferguson and Lovell (2017) to rely on a mix of annual and perennial crops together with farm animals. In South Africa and Zimbabwe, Didarali and Gambiza (2019) reported that crop diversity increased significantly upon practice of permaculture. In Indonesia, permaculture farms were reported by Putro and Miyaura (2020) as having a high degree of farm-level plant diversity with $>25-100$ species recorded in four farms.

Colocasia esculenta (taro) (Ahmed et al. 2020) and Capsicum frutescens (chili) (Yamamoto and Nawata 2005) were the most common crops found in 10 sites. Both species were said to be easily propagated either intentionally or unintentionally according to interviews. Colocasia esculenta was observed in low elevation waterlogged areas while Capsicum frutescens was reported to be propagated via droppings from chickens and birds according to practitioners. Annona muricata (guyabano) was the most common fruit-bearing tree found in 9 sites. Annona muricata was a multifunctional tree used by practitioners that they claim to provide many health benefits. The fruit eaten is fresh or made into juice concentrate while the leaves and bark were steeped for tea. 
Table 2. The total number of observed landscape components per site arranged by category. Glinoga has the most number of components (133) while Jubileeville had the least (56). Sites have an average of 99 landscape components with biotic category being the most abundant with an average of 56.5 per site.

\begin{tabular}{|c|c|c|c|c|c|c|c|}
\hline \multirow[t]{2}{*}{ Site } & \multicolumn{7}{|c|}{ Component category } \\
\hline & Abiotic & Biotic & Cultural & $\begin{array}{l}\text { Manmade } \\
\text { Structural }\end{array}$ & $\begin{array}{c}\text { Socio- } \\
\text { economic }\end{array}$ & Technological & Total \\
\hline Aloha House & 1 & 76 & 2 & 10 & 5 & 14 & 108 \\
\hline Alpas & 5 & 69 & 3 & 14 & 1 & 14 & 106 \\
\hline Cabiokid & 7 & 38 & 1 & 30 & 3 & 32 & 111 \\
\hline Eco-house & 1 & 26 & 2 & 5 & 2 & 46 & 82 \\
\hline Glinoga & 9 & 67 & 7 & 20 & 3 & 27 & 133 \\
\hline Jubileeville & 5 & 30 & 2 & 7 & 0 & 12 & 56 \\
\hline Kai Farms & 1 & 63 & 4 & 6 & 3 & 31 & 108 \\
\hline Lorenza's & 3 & 54 & 1 & 4 & 2 & 5 & 69 \\
\hline Nature Sanctuary & 3 & 40 & 14 & 14 & 1 & 33 & 105 \\
\hline Olaussen & 2 & 83 & 4 & 7 & 7 & 3 & 106 \\
\hline Tara Farms & 6 & 59 & 6 & 13 & 1 & 13 & 98 \\
\hline UmaLeng & 3 & 73 & 6 & 3 & 1 & 14 & 100 \\
\hline Total & 46 & 678 & 52 & 133 & 29 & 244 & 1182 \\
\hline Mean & 3.83 & 56.5 & 4.33 & 11.08 & 2.42 & 20.33 & 98.5 \\
\hline
\end{tabular}

Table 3. The soil test reported that the soil profile was generally suitable for planting crops with a soil $\mathrm{pH}$ range of 6 to 7.6. Soil samples were collected from September to November in 2018 during the rainy season.

\begin{tabular}{lclll}
\hline Location & \multicolumn{4}{c}{ Parameters } \\
\cline { 2 - 5 } & $\mathbf{p H}$ & $\mathbf{N}$ & $\mathbf{P}$ & \multicolumn{1}{c}{ K } \\
\hline Aloha House & 7.6 & Medium & High & Sufficient \\
Alpas & 6.8 & Low & High & Sufficient \\
Cabiokid & 6.0 & Low & High & Deficient \\
Eco-house & 7.6 & Medium & High & Sufficient \\
Glinoga & 6.0 & Low & High & Deficient \\
Jubileeville & 6.4 & Medium & High & Sufficient \\
Kai Farms & 6.4 & Medium & High & Sufficient \\
Lorenza's & 6.0 & Medium & High & Deficient \\
Nature Sanctuary & 7.6 & Medium & Low & Sufficient \\
Olaussen & 6.0 & Medium & Low & Sufficient \\
Tara Farms & 6.0 & Medium & High & Deficient \\
UmaLeng & 6.2 & Medium & High & Sufficient \\
\hline
\end{tabular}

Bambusoideae was found in 8 sites with its young shoots consumed as labong and its stems used as construction materials for making houses and furniture. The plant also functioned as living fences and windbreaks. Abelmoschus esculentus (okra) is an easy-to-grow vegetable that was found in 7 sites. Okra's resilient characteristics as a perennial crop makes it a favored highvalue crop for household consumption and selling. Carica papaya (papaya), Cucurma longa (turmeric), and Moringa oleifera (malunggay) were also documented in 7 sites. Ipomoea aquatica (kangkong) and Solanum lycopersicum (tomato) were found in 6 sites and were reported to be a regular part of the daily diet. Table 5 shows Gallus gallus domesticus (domestic chicken) was the most common type of poultry found in 6 sites while Sus philippinensis (Baboy ramo) was a common livestock observed in 4 sites.

In addition to plants and farm animals, bird species were also observed in all sites. Birds are an important component of the ecosystem as pollinators (Ford et al.
1979) and biocontrol (Lourenco 2021) for pest management in a permaculture landscape (Table 6). The role of birds in the permaculture landscape or agroecosystems in general needs to be studied further to determine its net effects (Olimpi et al. 2020).

Majority of 'manmade structural' components were found in Zone 0 but was also recorded in Zone 1 as seedling nurseries (Lorenza's, Laguna, Kai Farms); in Zone 2 as animal sheds (specifically for pigs in Tara Farms, Cabiokid, Aloha House); and in Zone 3 as a rice mill (Cabiokid). Although farm infrastructure is common components in an agricultural landscape, permaculture design allows manmade structural components to blend into the natural landscape (Singh and Nayyar 2015) with the use of renewable and locally available materials like Bambusoideae sp. (bamboo), Corypha elata (buri palm), and Saribus rotundifolius (anahaw) in combination with more traditional construction materials such as concrete and lumber. Use of natural materials, especially bamboo, in architecture are having a revival in Asia because of its abundance, multifunctionality, and sustainability as locally available materials. (Emamverdian et al. 2020; Maslucha et al. 2020).

'Technological' components documented machines, gadgets, and installations on the landscape. Components also include garden tools (shovels, trowels, rakes, garden hose) and appropriate technologies (trellises, raised beds, mulches, fertilizers, rainwater harvesters, etc.). These comprise the second most abundant category next to biotic components with an average of 20 technologies per site. Presence of technologies on the landscape demonstrated how permaculture practitioners interacted with the natural environment through the use of tools (Petri and Faust 2021). Furthermore, technological components created the connectivity of different components on the landscape. Examples of technology in other countries are projects such as borehole-garden permaculture in Malawi (Rivett et al. 2017) and the use of marine permaculture arrays (MPAs) in 
seascapes in Oman for climate change mitigation (Von Herzen et al. 2017).

'Socio-economic' components (Genus et al. 2021) were the least common on the landscape with only an average of 2 per site. The low number was expected because it only included infrastructures or spaces that generated income for the household such as retail stores, food processing facilities, and training/education facilities. Aloha House, Eco-house, Cabiokid, and Olaussen had small stores selling locally-made products. In Glinoga, a facility is dedicated to food processing. Alpas has a restaurant that serves local food while UmaLeng has a workshop facility for making local soap. These components were integrated into the permaculture landscape to initiate community engagement and provide an outlet for sharing and trading goods and services (Putro and Miyaura 2020).

Socio-economic components were also responsible for the financial stability of a permaculture design (Akhtar et al. 2015; Vitari and David 2017). Farms with limited revenue streams may struggle financially in the long term and must rely on other sources of income for working capital. The most common integration of socio-economic components into farm landscapes are agritourism and ecotourism services. Kitchen gardens in Thailand (Ip-SooChing and Veerapa 2013), food and hospitality-related services in Indonesia (Putro and Miyaura 2020), are among the most income-generating components of permaculture farms.

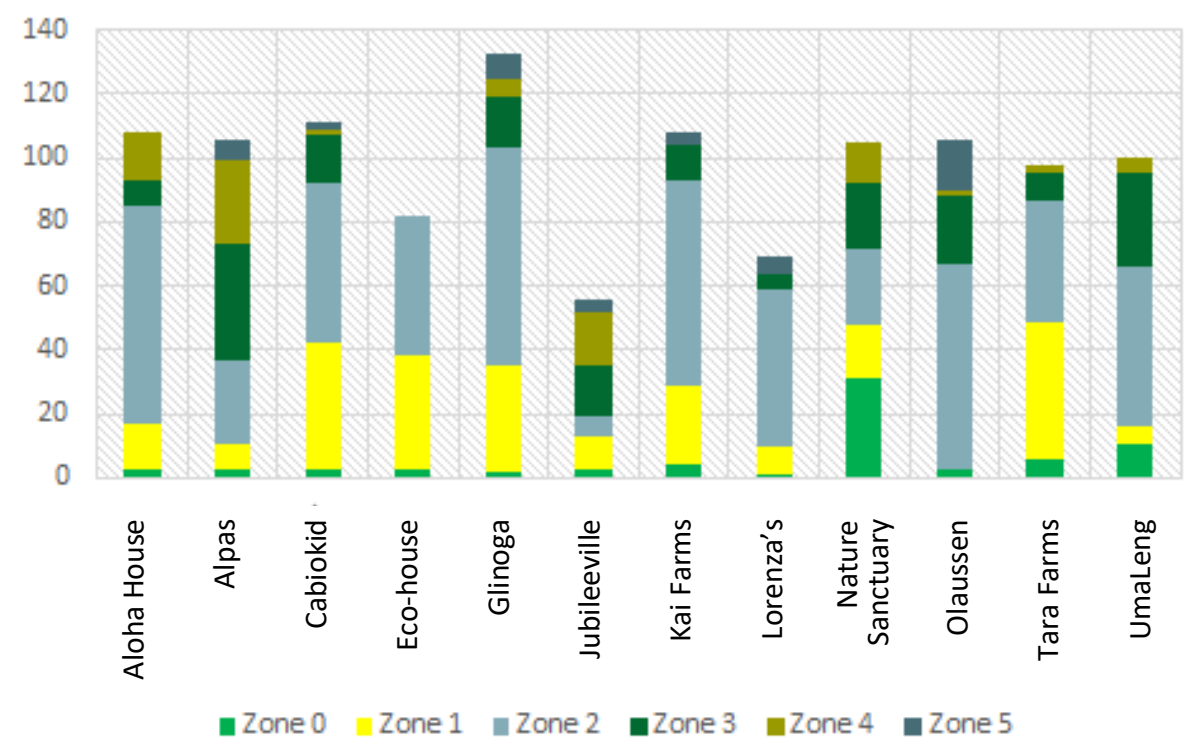

Figure 7. A stacked column chart shows the distribution of system components per zone. Zones 1 (garden) and 2 (grazing) report the most number of components

Table 4. Crop diversity per use category and crop life cycle. Data shows that Glinoga had the highest SR (65) and Eco-house had the lowest (21). Aloha House had the highest H index score (0.311) and Nature Sanctuary had the lowest (0.583)

\begin{tabular}{|c|c|c|c|c|c|c|c|c|c|c|c|}
\hline \multirow[b]{2}{*}{ Site } & \multirow[b]{2}{*}{$\mathbf{S R}^{*}$} & \multirow[b]{2}{*}{$\mathbf{H}^{* *}$} & \multicolumn{6}{|c|}{ Use category $(\%)$} & \multicolumn{2}{|c|}{ Life cycle } & \multirow[b]{2}{*}{ Tota } \\
\hline & & & $\begin{array}{l}\text { Feed } \\
\text { crops }\end{array}$ & Herbs & $\begin{array}{c}\text { Ornamen- } \\
\text { tals }\end{array}$ & $\begin{array}{l}\text { Fruit } \\
\text { crops }\end{array}$ & $\begin{array}{c}\text { Veg/Cereal } \\
\text { crops }\end{array}$ & Weeds & Annuals & $\begin{array}{c}\text { Peren- } \\
\text { nials }\end{array}$ & \\
\hline Aloha House & 62 & 0.311 & 0.016 & 0.242 & 0.113 & 0.274 & 0.355 & 0.000 & 0.226 & 0.774 & 1.000 \\
\hline Alpas & 45 & 0.345 & 0.000 & 0.067 & 0.311 & 0.378 & 0.244 & 0.000 & 0.133 & 0.867 & 1.000 \\
\hline Cabiokid & 24 & 0.504 & 0.000 & 0.042 & 0.125 & 0.292 & 0.542 & 0.000 & 0.208 & 0.792 & 1.000 \\
\hline Eco-house & 21 & 0.434 & 0.000 & 0.286 & 0.190 & 0.238 & 0.286 & 0.000 & 0.048 & 0.952 & 1.000 \\
\hline Glinoga & 65 & 0.314 & 0.015 & 0.062 & 0.215 & 0.462 & 0.231 & 0.015 & 0.123 & 0.923 & 1.000 \\
\hline Jubileeville & 48 & 0.334 & 0.021 & 0.021 & 0.333 & 0.458 & 0.167 & 0.000 & 0.104 & 0.917 & 1.000 \\
\hline Kai Farms & 52 & 0.331 & 0.000 & 0.327 & 0.096 & 0.212 & 0.365 & 0.000 & 0.231 & 0.769 & 1.000 \\
\hline Lorenza's & 58 & 0.356 & 0.017 & 0.121 & 0.259 & 0.293 & 0.190 & 0.138 & 0.172 & 0.828 & 1.000 \\
\hline Nature Sanctuary & 25 & 0.583 & 0.000 & 0.040 & 0.040 & 0.600 & 0.320 & 0.000 & 0.120 & 0.880 & 1.000 \\
\hline Olaussen & 36 & 0.444 & 0.000 & 0.083 & 0.083 & 0.278 & 0.556 & 0.000 & 0.250 & 0.750 & 1.000 \\
\hline Tara Farms & 62 & 0.320 & 0.016 & 0.194 & 0.548 & 0.108 & 0.129 & 0.016 & 0.161 & 0.871 & 1.000 \\
\hline UmaLeng & 56 & 0.377 & 0.000 & 0.214 & 0.214 & 0.196 & 0.339 & 0.000 & 0.107 & 0.893 & 1.000 \\
\hline
\end{tabular}

Note: $* \mathrm{SR}=$ Species Richness; $* * \mathrm{H}=$ Shannon-Wiener Diversity Index 
Table 5. Types of farm animals documented in permaculture landscapes

\begin{tabular}{|c|c|c|c|c|c|c|c|}
\hline \multirow[b]{2}{*}{ Animals } & \multicolumn{7}{|c|}{ Site } \\
\hline & 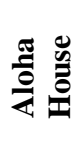 & $\frac{\mathfrak{E}}{2}$ & & 造 & 茴 & 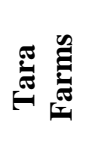 & \\
\hline Gallus gallus domesticus (domestic chicken) & + & + & - & - & + & - & + \\
\hline $\begin{array}{l}\text { Sus philippinensis (Philippine warty pig) or } \\
\text { Sus scrofa domesticus (domestic pig) }\end{array}$ & + & - & + & - & + & + & - \\
\hline Capra aegagrus hircus (domestic goat) & + & + & - & - & + & - & + \\
\hline Carina moschata (Muscovy duck) & + & - & + & - & - & + & + \\
\hline Bubalus bubalis carabanesis (Philippine carabao) & + & - & - & - & + & - & - \\
\hline
\end{tabular}

Table 6. Avifaunal species observed in permaculture landscapes during the rainy season (September to November of 2018)

\begin{tabular}{|c|c|c|}
\hline Site & Scientific name & Common name \\
\hline Aloha House & $\begin{array}{l}\text { Rhipidura nigritorquis } \\
\text { Aplonis panayensis }\end{array}$ & $\begin{array}{l}\text { Philippine Pied Fantail } \\
\text { Asian Glossy Starling }\end{array}$ \\
\hline Alpas & Lanius cristatus & Brown Shrike \\
\hline Cabiokid & Pycnonotus goiavier & Yellow-vented bulbul \\
\hline Eco-house & Dicaeum austral & Red-keeled Flowerpecker \\
\hline Glinoga & $\begin{array}{l}\text { Oriolus chinensis } \\
\text { Todirhamphus chloris }\end{array}$ & $\begin{array}{l}\text { Black-naped Oriole } \\
\text { Collared Kingfisher }\end{array}$ \\
\hline $\begin{array}{l}\text { Jubileeville/ } \\
\text { Tara Farms }\end{array}$ & Passer montanus & Eurasian Tree Sparrow \\
\hline Kai Farms & $\begin{array}{l}\text { Merops americanus } \\
\text { Cinnyris jugularis }\end{array}$ & $\begin{array}{l}\text { Rufous-crowned Bee-eater } \\
\text { Olive-backed sunbird }\end{array}$ \\
\hline Lorenza's & $\begin{array}{l}\text { Rhipidura cyaniceps } \\
\text { Merops philippinus } \\
\text { Orthotomus derbianus } \\
\text { Copsychus mindanensis }\end{array}$ & $\begin{array}{l}\text { Blue-headed Fantail } \\
\text { Blue-tailed bee-eater } \\
\text { Grey-backed Tailorbird } \\
\text { Philippine Magpie-Robin }\end{array}$ \\
\hline $\begin{array}{l}\text { Nature } \\
\text { Sanctuary }\end{array}$ & Nycticorax nycticorax & $\begin{array}{l}\text { Black-crowned Night } \\
\text { Heron }\end{array}$ \\
\hline & Cyornis rufigastra & Mangrove Blue Flycatcher \\
\hline Olaussen & Saxicola caprata & Pied Bushcat \\
\hline UmaLeng & $\begin{array}{l}\text { Amaurornis phoenicurus } \\
\text { Lonchura atricapilla } \\
\text { Ardeola speciosa }\end{array}$ & $\begin{array}{l}\text { White-breasted waterhen } \\
\text { Chestnut Munia } \\
\text { Javan Pond Heron }\end{array}$ \\
\hline
\end{tabular}

Finally, findings showed that permaculture landscapes have 'cultural' components (or 'cultural artifacts' in sociology) that identify the practitioner's personal values and religious beliefs (Ingram et al. 2014). Notable examples of such are Stations of the Cross in Nature Sanctuary and a chapel in Mountain Province which signify Christian influences. In addition, cultural components also provide leisure and recreational activities for family and friends. Examples are swimming pools in Tara Farms and Jubileeville and a basketball court in Glinoga. Although the documentation of cultural artifacts per se in permaculture is a relatively novel idea, cultural components are often expressed in the preservation of traditional or indigenous farming practices (Lwogo et al. 2010) such as in the cases of Bulgaria (Brawner 2015), El Salvador (Millner 2017), and Japan (Chakroun 2019).
The dominance of biotic components in almost all sites indicated that biodiversity was prioritized in permaculture designs (Hirschfeld and Van Acker 2021) while technological components were integrated to support biotic functioning and vice versa. The abundance of both of these component categories demonstrated how permaculture practitioners in the Philippines relied on technology, renewable resources, and the environment for daily needs.

In conclusion, the application of permaculture in farms is a strong example of sustainable agriculture in the Philippines. The way permaculture landscapes are structured into zones provides a diversity of components to support the cultivation of a variety of crops. In addition, design emphasis on biophysical diversity is a significant departure from the common practice of monoculture in conventional farming thus creating heterogeneous landscapes that resemble the appearance of forests more than farms. However, the scale of permaculture design is still limited to smallholder farms and home garden landscapes.

In theory, permaculture is scalable but examples of whole communities benefiting from the collective design efforts of multiple practitioners originating from a common locale have yet to be documented in the country. In addition to scale, annual crop yield from mixed cropping and agroforestry systems and the income derived from diversified revenue streams generated by farm multifunctionality were not included in the study.

Permaculture has yet to receive enough attention in order to attract institutional support to promote its practice. But with more research, especially on local examples of successful practitioners and their landscape designs, permaculture can provide the necessary design framework for restructuring our agricultural landscapes into diverse and productive ecosystems and redefining our relationship with nature.

\section{ACKNOWLEDGEMENTS}

The authors would like to thank The Southeast Asian Regional Center for Graduate Study and Research in Agriculture (SEARCA), Philippines for funding this project; the permaculture practitioners who participated in 
the study; and the research assistants who helped in the processing of data.

\section{REFERENCES}

Abdala PRZ, Mocellin GDP. 2010. Ecovillages and permaculture: A reference model for sustainable consumption? Encontro da ANPAD, Rio de Janeiro, Brazil, September 25-29.

Abiral B. 2019. Permaculture and ecological lifestyle: A restricted radicalism. In: Kinna R, Gordon U (eds.) Routledge Handbook of Radical Politics. Routledge, London.

Agisoft Photoscan (Version 1.2.6) [Computer Software]. 2016 http://www.agisoft.com/downloads/installer/.

Ahmed I, Lockhart PJ, Agoo EMG, Naing KW, Nguyen DV, Medhi DK, Matthews PJ. 2020. Evolutionary origins of taro (Colocasia esculenta) in Southeast Asia. Ecol Evol 10 (23): 13530-13543. DOI: 10.1002/ece3.6958

Akhtar F, Lodhi SA, Khan SS. 2015. Permaculture approach: linking ecological sustainability to business strategies. Manag Environ Qual 26 (6): 795-809. DOI: 10.1108/MEQ-01-2015-0001

Antrop M, Van Eetvelde V. 2017. Landscape Perspectives: The Holistic Nature of Landscape, Landscape Series 23. Springer, Berlin, Germany. DOI: 10.1007/978-94-024-1183-6_4.

Babac S. 2018. Permaculture zone planning using the triangular method Elec J Fac Civil Eng Osijek-e-GFOS 9 (17): 101-110. DOI: 10.13167/2018.17.10.

Berg H. 2002. Rice monoculture and integrated rice-fish farming in the Mekong Delta, Vietnam - Economic and ecological considerations. Ecol Econ 41 (1): 95-107. DOI: 10.1016/S0921-8009(02)00027-7

Bhandari D, Bista B. 2019. Permaculture: A key driver for sustainable agriculture in Nepal. Int J Appl Sci Biotechnol 7 (2): 167-173. DOI: 10.3126/ijasbt.v7i2.24647

Borelli P, Robinson DA, Fleischer LR, Fleischer LR, Lugato E, Ballabio C, Alewell C, Mausburger K, Modugno S, Schutt B, Ferro V, Bagarello V, van Oost K, Panagos P. 2017. An assessment of the global impact of 21 st century land use change on soil erosion. Nat Commun 8 (1): 1-13. DOI: 10.1038/s41467-017-02142-7

Borelli P, Robinson DA, Panagos P, Lugato E, Yang JE, Alewell C, Wuepper D, Montanarella L, Ballabio C. 2020. Land use and climate change impacts on global soil erosion by water (2015-2070). Proc Nat Acad Sci 117 (36): 21994-22001. DOI: 10.1073/pnas.2001403117

Brawner J. 2015. Permaculture in the margins: Realizing Central European regeneration. J Political Ecol 22 (1): 429. DOI: $10.2458 / \mathrm{v} 22 \mathrm{i} 1.21117$.

Buot IE, Osumi K. 2004. Satoyama landscape in the Philippines. J Nat Stud 3: 1-11.

Chakroun L, Droz D. 2020. Sustainability through landscapes: natura parks, satoyama, and permaculture in Japan. Ecosyst People 16 (1) 369-383. DOI: 10.1080/26395916.2020.1837244.

Chakroun L. 2019. Cultivating concrete utopia: Understanding how Japan's permaculture experiments are shaping a political vision of sustainable living. The International Academic Forum-Asian Conference for Sustainability, Energy and the Environment (ACSEE). Tokyo, Japan, May 20-22.

Cohen D, Crabtree B. 2006. Qualitative Research Guidelines Project. http://www.qualres.org.

Detera NS, Togni JP, Salazar KG, Sano MAA. 2014. Soil test kit: An extension tool of Central Bicol State University. J Manag Develop Stud 3: 50-61.

Devendra C, Thomas D. 2002. Crop-animal interactions in mixed farming systems in Asia. Agric Syst 71 (1-2): 27-40. DOI: 10.1016/S0308521X(01)00034-8

Didarali Z, Gambiza J. 2019. Permaculture: challenges and benefits in improving rural livelihoods in South Africa and Zimbabwe. Sustainability 11 (8): 2219. DOI: $10.3390 /$ su 11082219 .

Dmitri C, Effland AB, Conklin NC. 2005. The 20th Century Transformation of US Agriculture and Farm Policy. United States Department of Agriculture Economic Research Service, Economic Information Bulletin 3. Washington, DC, United States.

Do VH, Nguyen NL. 2020. Fruit tree-based agroforestry systems for smallholder farmers in Northwest Vietnam - A quantitative and qualitative assessment. Land 9 (11): 451 . DOI: 10.3390/land9110451.
Ekka SA, Rujner H. 2021. Next-generation swale design for stormwater runoff treatment: A comprehensive approach. J Environ Manag 279, 111756. DOI: 10.1016/j.jenvman.2020.111756.

Emamverdian A, Ding Y, Ranaei F, Ahmad Z. 2020. Application of bamboo plants in nine aspects. Sci World J 202. https://doi.org/10.1155/2020/7284203.

FAOSTAT. 2012. www.faostat.fao.org/

Ferguson RS, Lovell ST. 2017. Livelihoods and production diversity on U.S. permaculture farms. Agroecol Sustain Food Syst 41 (6): 588613. DOI: $10.1080 / 21683565.2017 .1320349$

Ferwerda W. 2016. 4 Returns, 3 Zones, 20 Years: A Holistic Framework for Ecological Restoration by People and Business for Next Generations. Rotterdam School of Management, Erasmus University.

Ford HA, Paton DC, Forde N. 1979. Birds as pollinators of Australian $\begin{array}{llllll}\text { plants. } & \mathrm{NZ} & \mathrm{J} & \mathrm{B} \text { ot } & 17 & \text { (4): 509-519. }\end{array}$ 10.1080/0028825X.1979.10432566.

Gabriel D, Sait SM. 2013. Food production vs. biodiversity: comparing organic and conventional agriculture. J Appl Ecol 50 (2): 355-364. DOI: $10.1111 / 1365-2664.12035$.

Genus A, Iskandarova M, Brown CW. 2021. Institutional entrepreneurship and permaculture: A practice theory perspective. Bus Strategy Environ 30 (3): 1454-1467. DOI: 10.1002/bse.2708.

Goncalves-Souza D, Verburg PH, Dobrovolski R. 2020. Habitat loss, extinction predictability and conservation efforts in the terrestrial ecoregions. Biol Conserv 246. DOI: 10.1016/j.biocon.2020.108579.

Grant T, Madden EM, Murphy RK, Smith KA, Nenneman MP. 2004 Monitoring native prairie vegetation: The belt transect method. Ecol Restor 22 (2): 106-111. DOI: 10.3368/er.22.2.106.

Hemenway T. 2009. Gaia's Garden: A Guide to Home-scale Permaculture 2nd Edition. Chelsea Green Publishing Company.

Hirschfeld S, Van Acker R. 2021. Review: ecosystem services in permaculture systems. Agroecol Sustain Food Syst 1-23. DOI: $10.1080 / 21683565.2021 .1881862$

Holmgren D. 2002. Permaculture: Principles \& Pathways Beyond Sustainability. Permanent Publications

Ingram J, Maye D. 2014. Learning in the permaculture community of practice in England: An analysis of the relationship between core practices and boundary processes. J Agric Educ Ext 20 (3): 275-290. DOI: 10.1080/1389224X.2014.887756.

Ip-soo-ching JM, Veerapa NK. 2013. Permaculture: Insights into kitchen gardens of environmental and eco-tourism operator in Thailand. Acta Hortic 1088: 633-636. DOI: 10.17660/ActaHortic.2015.1088.118.

Ismail NA, Affendi SM. 2015. Awareness and acceptability of permaculture in a residential landscape design: A case study of Denai Alam community. Res J Fish Hydrobiol 10 (14): 6-10.

Jensen PMJ, Phuc PD. 2008. Hygiene versus fertiliser: the use of human excreta in agriculture - A Vietnamese example. Int J Hyg Environ Health 211 (3-4): 432-439. DOI: 10.1016/j.ijheh.2007.08.011.

Kamchacha C. 2013. Investigating the Impact of Permaculture as a Tool for Mitigating and Adapting Climate Change. Permaculture and Community Development. [Bachelor's Thesis]. Share WORLD Open University, Malawi.

Kariuki RW, Western D. 2021. Assessing interactions between agriculture, livestock grazing and wildlife conservation land uses: A historical example from East Africa. Land 10 (1): 46. DOI: 10.3390/land10010046

Kaswanto RL, Nakagoshi N. 2014. Landscape ecology-based approach for assessing pekarangan condition to preserve protected area in West Java. In: Designing Low Carbon Societies in Landscape. Springer, Tokyo.

Kelly-Bisson C. 2013. Forests for The People: Resisting Neoliberalism through Permaculture Design. [Master's Thesis]. Carleton University, Canada.

Khachatryan H, Rihn A. 2020. Landscape aesthetics and maintenance perceptions: Assessing the relationship between homeowners' visual attention and landscape care knowledge. Land Use Policy 95, 104645. DOI: 10.1016/j.landusepol.2020.104645

Krebs J, Bach S. 2018. Permaculture - Scientific evidence of principles for the agroecological design of farming systems. Sustainability 10 (9): 3218. DOI: $10.3390 / \mathrm{su} 1009321$

Kremen C, Iles A, Bacon C. 2012. Diversified farming systems: an agroecological, systems-based alternative to modern industrial agriculture. Ecol Soc 17 (4): 44. DOI: 10.5751/ES-05103-170444.

Kremen C, Miles A. 2012. Ecosystem services in biologically diversified versus conventional farming systems: Benefits, externalities, and trade-offs. Ecol Soc 17 (4): 1-25. 
Kruger EM. 2015. Options for sustainability in building and energy: A South African permaculture case study. Energy Proc 83: 544-554. DOI: 10.1016/j.egypro.2015.12.174.

Le Roux JJ, Hui C, Castillo ML, Iriondo JM, Keet JH, Khapugin AA, Medail F, Rejmanek M, Theron G, Yannelli FA, Hirsch H. 2019. Recent anthropogenic plant extinctions differ in biodiversity hotspots and coldspots. Curr Biol 29 (17): 2912-2918. DOI: 10.1016/j.cub.2019.07.063.

Lourenco R, Pereira PF. 2021. Effect of vineyard characteristics on the functional diversity of insectivorous birds as indicator of potential biocontrol services. Ecol Indic 122, 107251. DOI: 10.1016/j.ecolind.2020.107251.

Maslucha L, Putriel YE, Rahma S, Handryant AN, Ramardani V. 2020. Contribution of bamboo materials in architecture education towards sustainable community development. IOP Conf Ser: Earth Environ Sci. 456, 012047. DOI: 10.1088/1755-1315/456/1/012047

Maughan MW, Flores JPC, Anghinoni I, Bollero G, Fernandez FG, Tracy BF. 2009. Soil quality and corn yield under crop-livestock integration in Illinois. Agron J 101 (6): 1503-1510. DOI: 10.2134/agronj2009.0068.

Millner N. 2017. The right to food is nature too: Food justice and everyday environmental expertise in the Salvadoran permaculture movement. Local Econ 22 (6): 764-783. DOI: 1016/j.agsy.2010.03.003.

Mollison B. 1988. Permaculture: A Designer's Manual. Tagari Publications, Australia.

National Mapping and Resource Information Authority (NAMRIA). 2015. Provincial Boundary Map. http://www.namria.gov.ph/

Olimpi EM, Garcia K, Gonthier DJ, de Master KT, Echeverri A, Kremen C, Sciligo AR, Snyder WE, Wilson-rankin EE, Karp DS. 2020. Shifts in species interactions and farming contexts mediate net effects of birds in agroecosystems. Ecol Appl 30 (5). DOI: 10.1002/eap.2115.

Paris TR. 2002. Crop-animal systems in Asia: socio-economic benefits and impacts on rural livelihoods. Agric Syst 71 (1-2): 147-168. DOI: 10.1016/S0308-521X(01)00041-5.

Petri H, Faust H. 2021. Understanding permaculturist motivations among residents of the "PermaKulturRaum" in Goettingen, Germany: A qualitative analysis. SN Soc Sci 1 (1): 1-26. DOI: $10.1007 / \mathrm{s} 43545$ 020-00024-2.

PHILGIS. 2019. http://philgis.org/.

Piratelli A, Pina-Rodrigues FCM, Raedig C. 2019. Integrating Biodiversity Conservation into Agroecosystem Management: Using Birds to Bring Conservation and Agricultural Production Together. Strategies and Tools for a Sustainable Rural Rio de Janeiro. DOI: 10.1007/978-3-319-89644-1_10

Power AG. 2010. Ecosystem services and agriculture: tradeoffs and synergies. R Soc Publishing 365 (1554): 2959-2971. DOI: 10.1098/rstb.2010.0143.

Putro RH, Miyaura R. 2020. Indonesian permaculture: Factors shaping permaculture farm systems in humid tropical Indonesia. Trop Agric Dev 64 (33): 113-124. DOI: 10.11248/jsta.64.113

Riolo F. 2018. The social and environmental value of public urban food forests: The case study of the Picasso Food Forest in Parma, Italy. Urban For Urban Green 45, $126225 . \quad$ DOI: 10.1016/j.ufug.2018.10.002.
Rist L, Feintrenie L, Levang P. 2010. The livelihood impacts of oil palm: smallholders in Indonesia. Biodivers Conserv 19 (4): 1009-1024. DOI: $10.1007 / \mathrm{s} 10531-010-9815-\mathrm{z}$.

Rivett MO, Halcrow AW. 2017. Local-scale water-food nexus: Use of borehole-garden permaculture to realise the full potential of rural water supplies in Malawi. J Environ Manag 209: 354-370. DOI: 10.1016/j.jenvman.2017.12.029.

Science for Environment Policy. 2017. Agri-environmental schemes: How to enhance the agriculture-environment relationship. Thematic Issue 57. Science Communication Unit, UWE, Bristol.

Shannon CE, Weaver W. 1949 The Mathematical Theory of Communication. University of Illinois Press, Urbana.

Singh A, Nayyar N. 2015. Biomimicry-An alternative solution to sustainable buildings. Int J Civ Eng Technol 2 (14): 96-101.

Sofo A, Sofo A. 2020. Converting home spaces into food gardens at the time of Covid-19 quarantine: All the benefits of plants in this difficult and unprecedented period. Hum Ecol Interdiscip J 48 (2): 131-139. DOI: $10.1007 / \mathrm{s} 10745-020-00147-3$.

Theunissen J. 1994. Intercropping in field vegetable crops: Pest management by agrosystem diversification - An overview. J Pest Sci 42 (1): 65-68. DOI: $10.1002 / p s .2780420111$.

United States Agency for International Development (USAID). 2016. USAID Regional Development Mission For Asia Mekong Adaptation and Resilience to Climate Change. Development Alternatives Incorporated. Maryland, USA.

United States Department of Agriculture (USDA). 2019. https://www.usda.gov/media/blog/2019/07/29/corn-americas-largestcrop-2019.

Van Der Lugt P, Van Den Dobbelsteen AAJF, Janssen JJA. 2006. An environmental, economic and practical assessment of bamboo as a building material for supporting structures. Constr Build Mater 20 (9): 648-656. DOI: 10.1016/j.conbuildmat.2005.02.023.

Vico G, Tamburino L, Rigby JR. 2020. Designing on-farm irrigation ponds for high and stable yield for different climates and risk-coping attitudes. J Hydrol 584, 124634. DOI: 10.1016/j.jhydrol.2020.124634.

Vitari C, David C. 2017. Sustainable management models: Innovating through permaculture. J Manag Dev 36 (1): 14-36. DOI: 10.1108/JMD-10-2014-0121

Von Herzen B, Theuretzbacher T, Newman J, Webber M, Zhu C, Katz JS, Ramaswamy M. 2017. A feasibility study of an integrated air conditioning, desalination and marine permaculture system in Oman. 10th International Conference on Thermal Engineering: Theory and Applications. Muscat, Oman, February 26-28, 2017.

Wiener N. 1939. The ergodic theorem. Duke Mathematical Journal, 5 [page numbers omitted in the paper]

Wiener N. 1948. Cybernetics. Wiley, New York

Wiener N. 1949. The interpolation, extrapolation, and smoothing of stationary time series. Wiley, New York

Whitefield P. 2004. Earth Care Manual: A Permaculture Handbook for Britain \& Other Temperate Climates. Permanent Publications.

Yamamoto S, Nawata E. 2005. Capsicum frutescens L. in Southeast and East Asia, and its dispersal routes into Japan. Econ Bot 59 (1): 18-28. DOI: 10.1663/0013-0001(2005)059[0018:CFLISA]2.0.CO;2. 